Servet Atayeter
Turkish Standards Institution, satayeter@tse.org.tr, Ankara-Turkey

\begin{tabular}{l|l}
\hline DOI & http://dx.doi.org/10.12739/NWSA.2019.14.4.E0048
\end{tabular}

ORCID ID 0000-0003-0695-1184

CORRESPONDING AUTHOR Servet Atayeter

\title{
PRODUCTIVITY OF ROTIFER Brachionus plicatilis CULTURED UNDER BATCH SYSTEM BY USING SUGAR BEET MOLASSES AS A SUBSTITUTE MEDIUM
}

\section{ABSTRACT}

This study deals with the determination of availability of sugar beet molasses as a nutritional enrichment factor for rotifer cultures. A series of experiments under varying conditions such as ratio of sugar beet molasses in the nutrient complex were carried out in order to determine the effectiveness of sugar beet molasses as a carbohydrate and mineral source for the purpose of aquacultural operations. The culture water of Brachionus plicatilis with the salinity of 38\% was treated through mechanical filtration and UV sterilization. 1 T cylindro-conical tanks are utilized for rotifer culture. Parameters of culture water were stabilized at values as following; Oxygen concentration:5 to 10 ppm, temperature: $27^{\circ} \mathrm{C}$ and $\mathrm{pH}: 6.8$ to 7.4. Rotifers were counted by using Sedgewick Rafter Cell on a daily basis in order to determine increase of number of individuals. The study was conducted as 3 different trial groups, each consisting three separate tanks, so triplicate determinations were obtained. For the Group I, 10\% molasses by weight of Culture Selco Plus (200 gr Selco Plust20 gr molasses per tank) was added 6 times a day with 4 hours' intervals. For the Group II, 20\% molasses by weight of Culture Selco Plus (200gr Selco Plus+40gr molasses per tank) was added and lastly for the control group, Group III, no molasses has been added and $200 \mathrm{gr}$ Culture Selco Plus was only added per tank. The addition of molasses to nutritive complex has a decreasing effect on the number of rotifer and increasing effect on the number of ciliate. From the study, it is clear that sugar beet molasses should not be used as an additional nutritional factor for rotifer cultures due to its decreasing effect on the number rotifers and stimulating effect on the ciliate booming. Addition of $10 \%$ and $20 \%$ molasses resulted in $31.4 \%$ and $23.3 \%$ decrease in number of rotifers at the time of $\mathrm{T} 3$, respectively. On the other hand, it was observed that addition of molasses in the nutritive complex has not affected on the percentage of rotifers bearing eggs.

Keywords: Sugar Beet Molasses, Ciliate, Brachionus Plicatilis, Rotifer, Culture Medium

\section{INTRODUCTION}

"An area of major concern in fish hatcheries is the provision of a dependable, nutritionally complete, economical food source for the fish larvae. In hatcheries, fish are raised from the eggs to the juvenile stages, until they are suitable for transfer to ponds or cages. In intensive fish culture, the most critical phase is acclimatization of fish with absorbed yolk sac for feeding. A crucial step in the intensification process of larval rearing of several marine fish species, is definitely the successful mass production of rotifers. There are thousands of zooplankton species which could serve as larval food in aquaculture but only few have high reproductive capacity. The rate of

How to Cite:

Atayeter, S., (2019). Productivity of Rotifer Brachionus plicatilis Cultured Under Batch System By Using Sugar Beet Molasses as a Substitute Medium, Qualitative Studies (NWSAQS), 14(4):43-49, DOI: 10.12739/NWSA.2019.14.4.E0048. 
reproduction depends on salinity, temperature, food quality, food quantity and is strain specific. Brachionus plicatilis is probably the most commonly grown rotifer for the mass cultivation of larval fish in hatcheries around the world" [8, 10, 16, 7, and 13].

"Even though zooplankton contain their own enzymes that aid fish in digesting them, rotifers are deficient in essential fatty acids and possibly other nutrients. To be nutritionally adequate, rotifers are often enriched before giving them to the fish. There are several artificial specialized products for rotifer culture. They allow to culture rotifers of a guaranteed nutritional value, which has proven to be very important in the first weeks of marine larval fish rearing. Due to some inconveniences, intensive- producing hatcheries use culture Selco instead of microalgae, widespread. The most frequently used formulated diet in rotifer culture in Europe is Culture Selco (CS) available under a dry form. It has been formulated as a complete substitute for live microalgae and at the same time guarantees the incorporation of high levels of $\mathrm{EFA}$ and vitamins in the rotifers. The chemical composition of Culture Selco Plus is given as:Moisture: \%5,

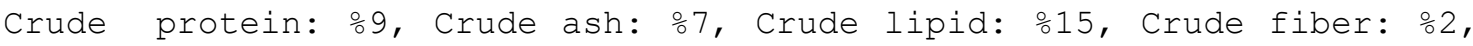
Phosphorus: ㄷ, Vit. A:500.000IU/kg, Vit. D3:50.000 IU/kg, Vit. $\mathrm{E}: 3600 \mathrm{mg} / \mathrm{kg}$, Vit. C:4000mg/kg, Total HUFA: min. $17 \mathrm{mg} / \mathrm{g}$ dwt" [8, 7, 6, and 15]. "A comparative study on the rotifer production systems done in Turkey, resulted at 927 rotifer/ml and 2750 rotifer/ml on the 14 th day and 10th day, respectively with the rate of $50 \%$ water change a day. Following experiments conducted with starting 570 rotifer/ml, showed that the concentration of rotifers reached 1000 rotifer/ml and 1700 rotifer/ml on the 5th and 15th days, respectively at the rate of 500\% water change a day. With the starting concentration of 810 rotifer/ml and at the same rate of water change, study resulted 1560 rotifer/ml, 3000 rotifer/ml and 3760 rotifer/ml on the 4th, 6 th and 8 th days, respectively" [3] .

"Salinity, temperature, dissolved oxygen, $\mathrm{pH}$, Ammonia ( $\left.\mathrm{NH}_{3}\right)$ and ciliates are the most important parameters for rotifer cultures. Ciliates are not desired in intensive cultures since they compete for feed with the rotifers. The appearance of these ciliates is generally due suboptimal rearing conditions, leading to less performing rotifers and increased chances for competition. Ciliates produce metabolic wastes which increase the $\mathrm{NO}_{2}^{-} \mathrm{N}$ level in the water and cause a decrease in $\mathrm{pH}$. However, they have a positive effect in clearing the culture tank from bacteria and detritus" [6]. "Beet molasses is the residual syrup from the processing of sugar beet from which no more sugar can be crystallized by conventional means" [4]. "On the basis of 73-79\% dry matter and as of dry matter, the total sugar content which is predominantly consisting sucrose in sugar beet molasses is approximately 50\%. Minor carbohydrates are glucose, fructose, raffinose and some other oligo- or polysaccharides. Their concentration is below $1 \%$ and depends to a significant extent on the manufacturing process. Crude protein and crude fibre contents are reported as 6.6-11.1\% and 0.0-0.3\% respectively. Major cations are potassium (3.2-4.7\%) followed by sodium (0.6-1.9\%), calcium (0.1-0.5\%) and magnesium (0.01-0.3\%). Their content depends mainly on soil type and water availability. Additionally, the calcium and sodium content is influenced by processing practices. About 20\% of the total mass consists of non-sucrose organic matter, in particular of non-protein nitrogen (NPN) containing substances, such as betaine (4-5\%). In addition, molasses contains free and bound amino acids, pryrrolidone carboxylic acid (a conversion product of glutamine), peptides and nucleic acid components (3-4\%). In the manufacturing process most of the amino acids undergo changes so that less than the amounts expected from beet roots are found in molasses. Molasses contains up to 4\% of organic acids 
predominantly lactic acid from the degradation of invert sugar (up to 1.7\%) followed by malic, citric, fumaric, and oxalic acid. Molasses contains only low levels of trace elements except for iron. Molasses

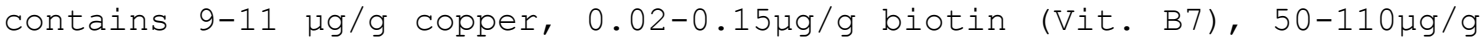

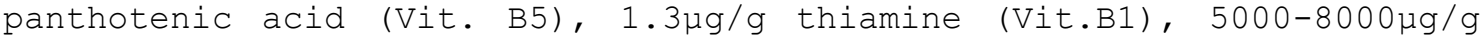
inositol. The main inorganic anions are chloride (1.0-3.0\%), sulfate (0.6-2.0\%), nitrate (0.3-0.8\%) and traces of phosphate $(0.1-0.5 \%)$ and nitrite $(3.0-170 \mathrm{mg} / \mathrm{kg})$. $\mathrm{pH}$ of molasses is reported as 7 to $8.76 . "$ [4, 14, 18, 12, and 17]. Koru and Perçin [11] reported that many species including rotifers live, feed and reproduce in a salt marsh and in solar saltworks in Çamaltı, İzmir, Turkey.

\section{RESEARCH SIGNIFICANCE}

The purpose of this study is to determine the availability of sugar beet molasses to use as additional nutritional constituent for rotifer cultures. Since research work on the use of alternative nutrient sources in the field of rotifer cultivation is very limited, this study can contribute future research.

\section{EXPERIMENTAL METHOD-PROCESS}

This study was conducted in the rotifer units of sea bream and sea bass hatchery facilities of Kılıç Group of Companies in Ören/Milas, Muğla, Turkey. In this study, the rotifer, Brachionus plicatilis (Mueller, 1786) was used [2 and 9]. The water used in the Production Unit is obtained from the underground water source (Artesian well) and its salinity is 38\% The water was treated before its use. The mechanical filtration which is as the first stage of the treatment process followed by UV sterilization. Whole treatment process allows suspended matters and pathogens are eliminated. The batch system is used for rotifer culture. This study is conducted in cylindro-conical tanks of $1 \mathrm{~T}$ capacity. Oxygen concentration of water was maintained between 5 to 10 ppm, temperature was almost constant at $27^{\circ} \mathrm{C}$ and $\mathrm{pH}$ was 6.8 to 7.4 . Intensity of light was measured as 520 Lux at the surface of the tank. The rotifers were counted by using Sedgewick Rafter cell with 1 day intervals. The ciliate, Amphorides amphora Claparéde \& Lachmann, 1858 [19], an undesired organism, has also been detected and counted in rotifer tanks [1]. The study was conducted as three experimental groups based on the relative proportion of molasses and each group in triplicates. In the Group I, 10\% molasses by weight added in nutritive complex, Culture Selco Plus (200gr Selco Plus+20gr molasses 6 times a day per tank, dividing into 4 hours intervals). $20 \%$ molasses by weight was added in nutritive complex for Group II (200gr Selco Plus+40gr molasses per tank). For the control group, Group III, no molasses has been added and only $200 \mathrm{gr}$ Culture selco Plus per tank used for nutrition purposes. Related data obtained from the experiments statistically evaluated by using the techniques of Factorial Analysis of Variance with Repeated Measurement (ANOVA) and Duncan Tests [5 and 20]. Mean Values and Standard Errors were calculated from triplicate determinations, each obtained from three separate tanks.

\section{FINDINGS AND DISCUSSIONS}

The results of rotifer trials are given in Table 1, Figure 1, Figure 2 and Figure 3. The results of statistical analysis applied on data obtained from the study are as following: Analysis of Variance which is applied on data obtained from the rotifer trials showed that interaction between Times ( $T$ ) and Groups (GR) in relation to number of rotifers is statistically significant $(\mathrm{P}<0.05)$. Duncan Test showed that, on the time of T3, the difference between the means of the number of rotifers only in GRI and GRIII and between GRII and GRIII found 
statistically significant $(P<0.05)$. In each of the groups, there is no difference between $\mathrm{TO}$ and $\mathrm{T} 1$, but there are statistically significant differences between $\mathrm{T} 2$ and $\mathrm{T} 3, \mathrm{~T} 2$ and $\mathrm{T} 0, \mathrm{~T} 2$ and $\mathrm{T} 1, \mathrm{~T} 3$ and $\mathrm{T} 0$, and finally T3 and T1. Analysis of Variance which is applied on the data of percentage of rotifers with eggs showed that there is a difference between times when we disregard Groups $(\mathrm{P}<0.05)$. According to the results of Duncan Test, there is no difference between the times of T0 and T3 and between $\mathrm{T} 1$ and T2, otherwise, T0 differs from T1 and T2. Similarly, T3 differs from T1 and T2. Analysis of Variance which is applied on the data of number of ciliate showed that there is a difference between groups also $(P<0.05)$. According to the results of Duncan Test, there is difference between GRI and GRII and between GRII and GR III. The difference between GRI and GR III is not statistically significant. Addition of $20 \mathrm{gr}$ or $40 \mathrm{gr}$ molasses has no noticeably effect on the number of rotifers in the tanks. But, use of molasses in combination with selco Plus has a decreasing effect on the number of rotifers up to 25\% at the time of $\mathrm{T} 3$. In each of the groups, at the time of $\mathrm{T} 1$, the percentage of egg bearing rotifers has increased sharply and reached to their peak levels. On the time of T3, the levels went back down to nearly their starting levels. Addition of $40 \mathrm{gr}$ molasses (GRII) showed the best performance among others, in order to reach a maximum percentage of egg bearing rotifers at the time of $\mathrm{T} 1$.

Table 1. Density of rotifers, rotifers with eggs and ciliates in relation to time and composition of nutritive complex

\begin{tabular}{|c|c|c|c|c|c|c|c|c|c|c|}
\hline \multirow[b]{3}{*}{ Time (Days) } & \multicolumn{3}{|c|}{ GRI } & \multicolumn{3}{|c|}{ GRII } & \multicolumn{3}{|c|}{ GRIII } & \multirow[b]{2}{*}{$\begin{array}{c}\text { EGG } \\
\text { BEARING } \\
\text { ROT.\% }\end{array}$} \\
\hline & \multirow{2}{*}{ 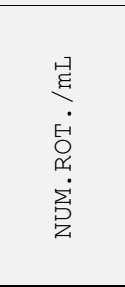 } & \multirow{2}{*}{ 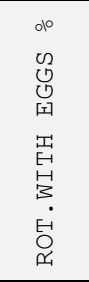 } & \multirow{2}{*}{ 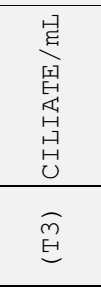 } & \multirow[t]{2}{*}{$\begin{array}{l}\text { 旦 } \\
\text { O } \\
\text { 品 } \\
\sum_{3}\end{array}$} & \multirow{2}{*}{ 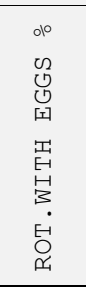 } & \multirow{2}{*}{ 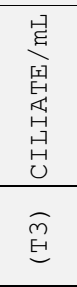 } & \multirow[t]{2}{*}{$\begin{array}{l}\dot{1} \\
0 \\
\underbrace{}_{1} \\
\dot{\Sigma} \\
\text { 号 }\end{array}$} & \multirow{2}{*}{ 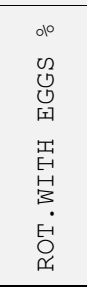 } & 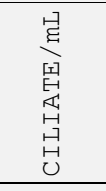 & \\
\hline & & & & & & & & & $\widehat{\text { En}}$ & $\begin{array}{l}\text { Total } \\
\text { Mean* }\end{array}$ \\
\hline T0 & 466 & 18 & & 496 & 26 & & 486 & 16 & & \\
\hline T0 & 478 & 24 & & 466 & 23 & & 477 & 28 & & \\
\hline T0 & 504 & 19 & & 497 & 20 & & 485 & 22 & & \\
\hline Mean & $482.66^{\mathrm{CA}}$ & 20.33 & & $486.33^{\mathrm{CA}}$ & 23 & & $482.66^{\mathrm{cA}}$ & 22 & & $21.77^{a}$ \\
\hline 土Std.Err. & 11.2 & 1.86 & & 10.2 & 1.73 & & 2.85 & 3.46 & & \\
\hline $\mathrm{T} 1$ & 520 & 41 & & 558 & 42 & & 574 & 26 & & \\
\hline $\mathrm{T} 1$ & 536 & 41 & & 570 & 48 & & 666 & 50 & & \\
\hline $\mathrm{T} 1$ & 578 & 44 & & 552 & 44 & & 704 & 46 & & \\
\hline Mean & $544.66^{\mathrm{CA}}$ & 42 & & $560^{\mathrm{CA}}$ & 44.66 & & $648^{\mathrm{cA}}$ & 40.66 & & $42.44^{b c}$ \\
\hline \pm Std.Err. & 17.3 & 1 & & 5.29 & 1.76 & & 38.6 & 7.42 & & \\
\hline $\mathrm{T} 2$ & 690 & 44 & & 1140 & 23 & & 952 & 46 & & \\
\hline $\mathrm{T} 2$ & 862 & 29 & & 976 & 44 & & 1126 & 31 & & \\
\hline $\mathrm{T} 2$ & 1363 & 33 & & 906 & 40 & & 1255 & 37 & & \\
\hline Mean & $971.66^{\mathrm{aA}}$ & 35.33 & & $1007.33^{\mathrm{aA}}$ & 35.66 & & $1111^{\mathrm{aA}}$ & 38 & & $36.33^{c}$ \\
\hline \pm Std.Err. & 202 & 4.48 & & 69.3 & 6.44 & & 87.8 & 4.36 & & \\
\hline T3 & 1264 & 27 & 13 & 1580 & 20 & 52 & 1890 & 28 & 13 & \\
\hline T3 & 1182 & 13 & 11 & 1522 & 25 & 41 & 1913 & 19 & 7 & \\
\hline T3 & 1670 & 12 & 22 & 1502 & 25 & 63 & 2198 & 25 & 18 & \\
\hline Mean & $1372^{\mathrm{bB}}$ & 17.33 & $15.33^{\mathrm{A}}$ & $1534.66^{\mathrm{bB}}$ & 23.33 & $52^{\mathrm{B}}$ & $2000.33^{\mathrm{bA}}$ & 24 & $12.66^{\mathrm{A}}$ & $21.55^{a}$ \\
\hline \pm Std.Err. & 151 & 4.84 & 3.38 & 23.4 & 1.67 & 6.35 & 99.1 & 2.65 & 3.18 & \\
\hline
\end{tabular}

*Total Mean: Mean of Group Means at each time interval

Different capital superscripts in the same row indicate significant differences (P<0.05) Different lowercase superscripts in the same column indicate significant differences $(\mathrm{P}<0.05)$

T0: The time at which the experiment starts

T1: 1 day (24 hours)

T2: 2 days (48 hours)

T3: 3 days (72 hours)

Group I: 200gr Selco Plus+20gr molasses

Group II: $200 \mathrm{gr}$ Selco Plus+40gr molasses

Group III (Control group): 200gr Culture Selco Plus 


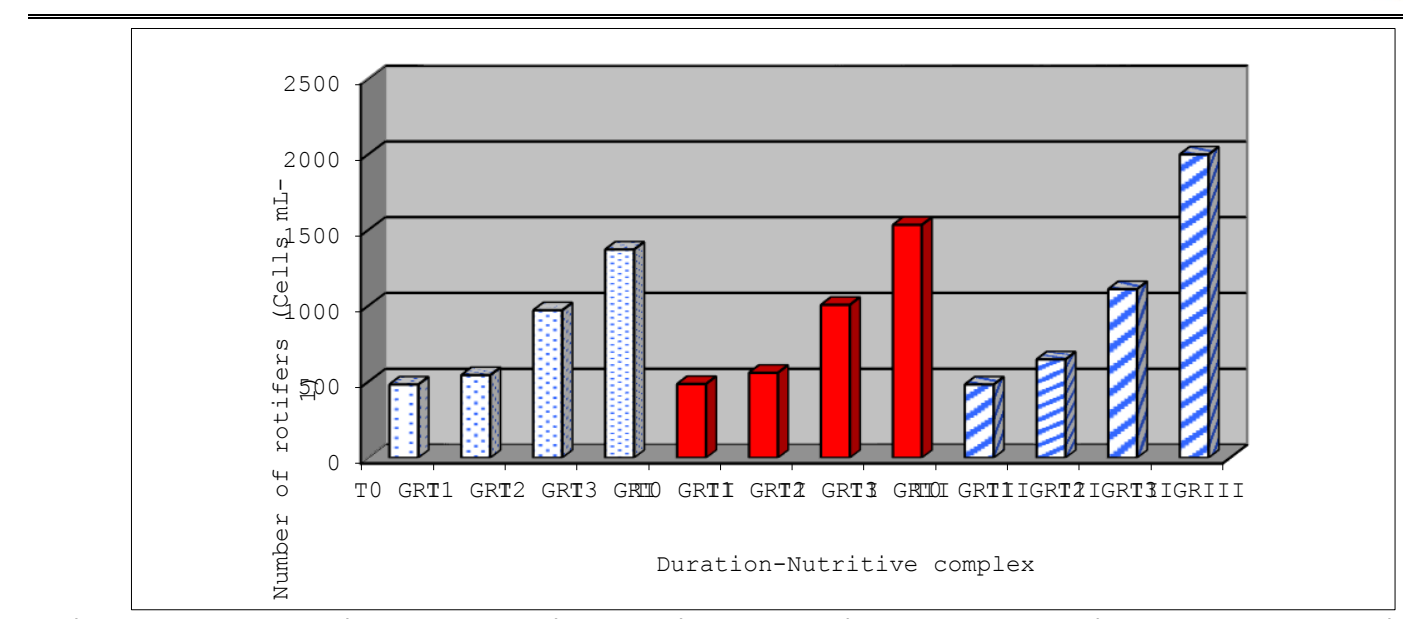

Figure 1. Density of rotifers in relation to duration and composition of nutritive complex

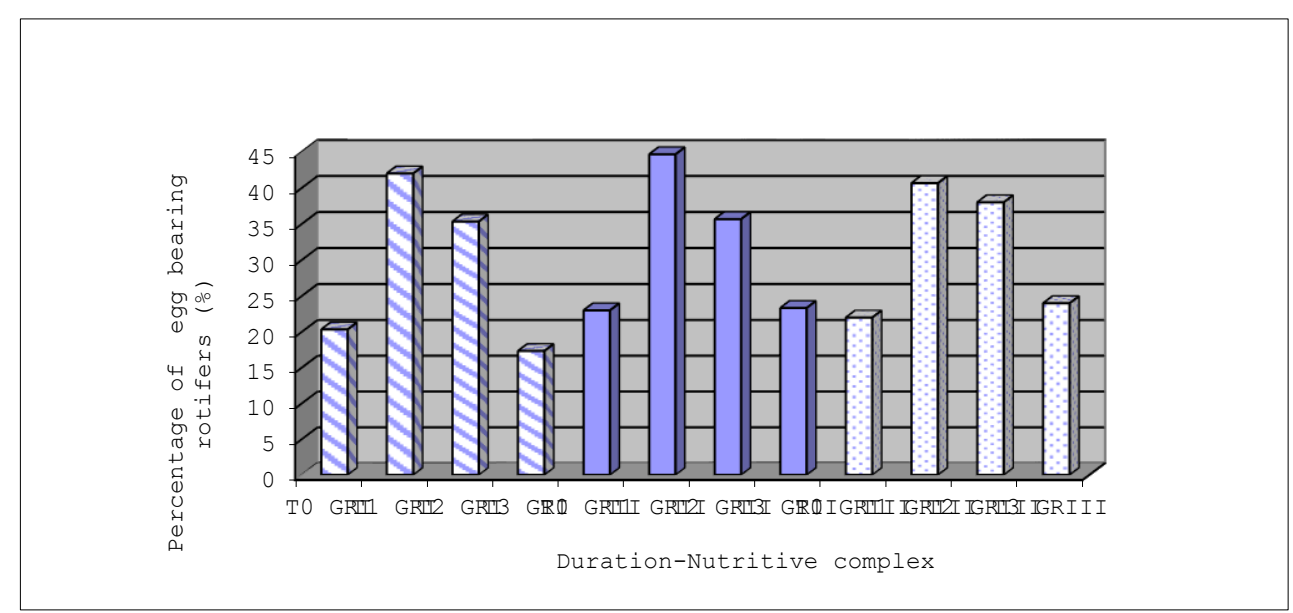

Figure 2. Percentage of egg bearing rotifers in relation to duration and composition of nutritive complex (을

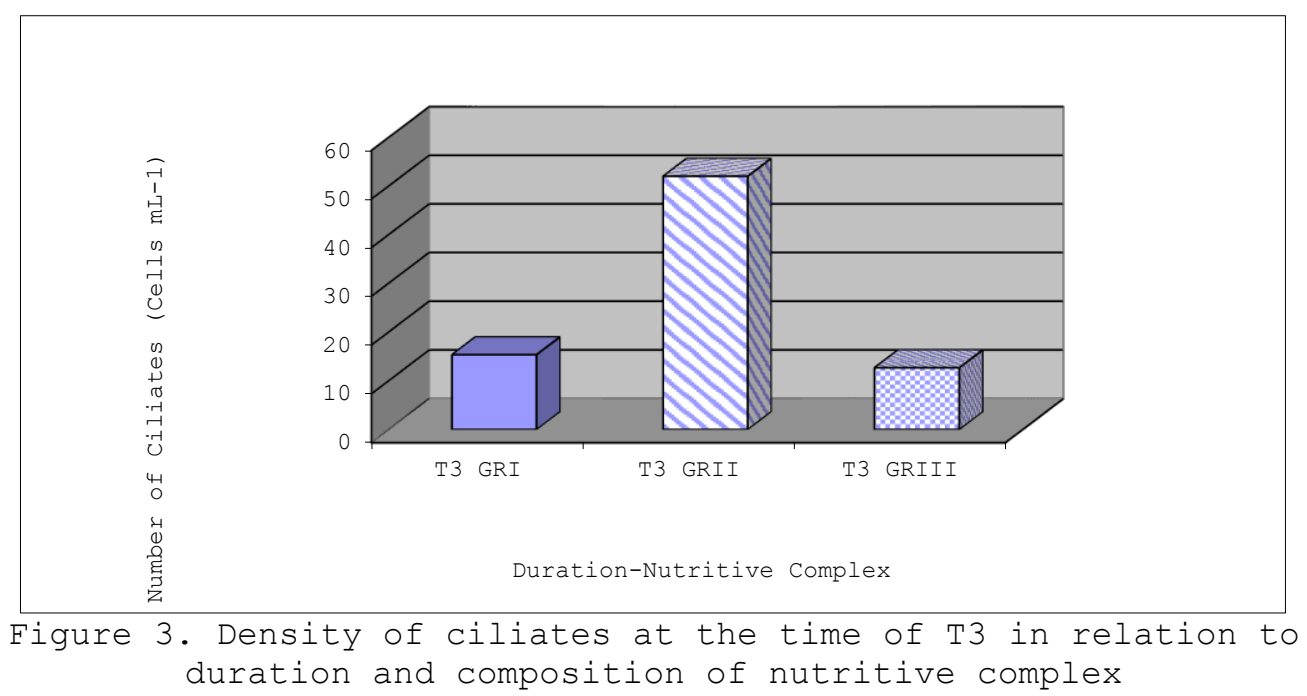

\section{CONCLUSION AND RECOMMENDATIONS}

According to data on ciliate proliferation in rotifer trials, no distinct difference observed between the numbers of ciliate in Group I and Group III on the time of T3. It is obvious that, addition of $40 \mathrm{gr}$ molasses is significantly encouraging for ciliate booming. In comparison 
of the contents of Selco and sugar beet molasses, it is clear that; sugar beet molasses includes sodium, B group vitamins and copper which are not present in selco. Although sugar beet molasses can be assumed as supporting selco for deficient components, copper in sugar beet molasses possibly has an inhibitory effect on rotifer reproduction. Generally, it can be seen that, the addition of molasses to nutritive complex caused decreasing in the number of rotifers and increasing effect in the number of ciliate. From the study, it is clear that sugar beet molasses should not be used as an additional nutritional factor for rotifer cultures due to its decreasing effect on the number rotifers and stimulating effect on the ciliate proliferation. Addition of $10 \%$ and $20 \%$ molasses resulted in $31.4 \%$ and $23.3 \%$, decrease in number of rotifers at the time of T3, respectively. Addition of molasses in the culture medium has had no remarkable effect on the percentage of rotifers with eggs. In this study, "Batch culture" system has been used and in order to prevent ciliate increase, "Flow-through" system could be used instead. Furthermore, sugar beet molasses can be useful in compensating Selco's carbohydrate and mineral deficiency (with the exemption of phosphorus) provided that it is used in a furher processed and meticulously formulated form. Having a pH value of 7 to 8.76, [4, 14, 18, 12, and 17] molasses may have a compensatory effect against decrease in pH caused by ciliate metabolic wastes in tanks [6]. When the results of 3 days (T3=72 hours) are compared with that of rotifer concentrations reported by Çelik et.al. [3], GRI in which $20 \mathrm{gr}$ molasses combined with Selco, used showed better performance than of 14 days, 5 days. For Group II in which $40 \mathrm{gr}$ molasses combined with selco, rotifer concentrations are higher than of 14 day and 5 days and approximately same on the 4 th day. With the lower starting concentration of rotifer, GRII reached an approximate concentration of 15 days within 3 days. In case of using molasses for nutritional purposes, some precautions should be taken into consideration in order to control excessive ciliate proliferation. These may include washing off ciliate by using special filters, using specific chemical agents inhibiting ciliate booming and autoclaving the molasses stock to control microorganisms including ciliate.

\section{ACKNOWLEDGEMENTS}

I would like to extend my gratitude to the Kılıç Group of Companies and especially to its staff, Technical Director, Aqua cultural Engineer M. Alaaddin Özkara for their support to this study and to Prof.Dr. Muhip Özkan, from Ankara University, for his precious support provided in statistical analysis.

\section{REFERENCES}

[1] Balkıs, N., (2004). Tintinnids (Protozoa: Ciliophora) of the Büyükçekmece Bay in the Sea of Marmara, Sci Mar, 68(1):33-44.

[2] CCAP, (2010). Brachionus plicatilis (Mueller 1786) CCAP 5010/4, http: / / www . ccap.ac.uk/results . php?mode=basic\&strainsearch=brachi onustplicatilis\# (Cited 16.01.2010).

[3] Çelik, İ., Önal, U. ve Ergün, S., (2007). Yüksek Yoğunluklu Rotifer, Brachionus plicatilis Üretim Sistemi Performansı, XVI. Ulusal Su Ürünleri Sempozyumu, 04-07 Eylül, Muğla.

[4] Draycott, A.P., (2006). World Agriculture Series-Sugar Beet, Blackwell Publishing Ltd, p.451.

[5] Düzgüneş, O., Kesici, T. ve Gürbüz, F., (1983). Statistical Methods (İstatistik Metodları), A.Ü. Ziraat Fakültesi Yayınları:861, Ankara, ss:185-186.

[6] FAO, (2010). Manual on the Production and Use of Live Food for Aquaculture. http://www.fao.org/docrep/003/W3732E/w3732e00.HTM (Cited 23.09.2010). 
[7] Granvil, D.T., (1995). The Production of Live Food Organisms for Fishes. In: Nash CE, Novotny AJ: World Animal Science, Production of Aquatic Animals-Fishes, Elsevier Science B.V., The Netherlands.

[8] INVE, (2010). Rotifer Culture and Enrichment. http: //www. inve.com/INVE-Aquaculture/English/Products/Fishhatcheries/rotifer-culture-enrichment/page.aspx/1073 (Cited 21.09.2010).

[9] ITIS, (2010). Brachionus plicatilis (Mueller 1786) Taxonomical Serial, Number: 58435, http://www.itis.gov/servlet/SingleRpt/SingleRpt (Cited $16.02 .2010)$.

[10] Joachim, W.H. and Felicitas, P., (2000). Handbook on Ingredients for Aquaculture Feeds, Kluwer Academic Publishers, The Netherlands, 2000.

[11] Koru, E. and Perçin, F., (2018). Characteristics of Biological Systems in Çamaltı Solar Saltworks (İmir/Turkey), Qualitative Studies, 13(3):15-25, DOI: 10.12739/NWSA.2018.13.3.E0036.

[12] Kütahya Şeker, (2010). Melas, www.kutahyaseker.com.tr/kupseker/melas.asp Cited 09.06.2010).

[13] Lubzens, E., Zmora, O., and Barr, Y., (2001). Biotechnology and Aquaculture of Rotifers, Hydrobiologia 446/447:337-353. In: Developments in Hydrobiology, Rotifera IX, Sanoamuang L, Segers H, Shiel R.J. and Gulati R.D., Kluwer Academic Publishers.

[14] OECD, (2002). Consensus Document on Compositional Considerations for New Varieties of Sugar beet: Key Food and Feed Nutrients and Anti-Nutrients, Environment Directorate, Organisation for Economic Co-operation and Development (OECD), Paris 2002 (ENV/JM/MONO (2002)4, Series on the Safety of Novel Foods and Feeds, No:3).

[15] Özbaş, B., Göksan, T. ve Ak, İ., (2006). Brachionus plicatilis (Rotifer)'in Farklı Besin Ortamlarında Büyümesi, E. Ü. Su Ürüleri Dergisi, Cilt 23, Ek (1/2):279-282.

[16] Özdemir, N., Alak, G. ve Çiltaş, A., (2007). Rotifer Kültüründe Biyoteknolojik Çalışmalar, Ulusal Su Günleri, 16-18, Antalya.

[17] Stevens, C.V. and Verhe, R., (2004). Renewable BioresourcesScope and Modification for Non-food Applications, John Wiley\&Sons Ltd., England.

[18] WoRMS, World Register of Marine Species, (2019). Available: http: //marinespecies.org/aphia.php?p=taxdetails\&id=23768 (Cited 26.09.2019).

[19] Türkşeker, (2010). Ürünler, www.turkseker.gov.tr/Urunler

[20] Zar, J.H., (1999). Biostatistical Analysis, 4th ed., 662 pp., Prentice Hall Inc., NJ. 